\title{
Die religieuse in Afrika-sosialisme
}

\author{
C J Viljoen
}

\section{Inleiding}

\section{Agtergronde}

Dit is eers nodig om oor Afrika-sosialisme as sodanig 'n paar dinge te sê, ten einde 'n duidelike begrip te vorm van wat alles hierby betrokke is. Daar moet dus oor sosialisme gepraat word, en ook oor Afrika, sy mense se politieke, maatskaplike en ekonomiese toestande, hulle soeke en ideale. Dit alles, om maar 'n paar dinge te noem. Binne hierdie raamwerk is die mens van Afrika belangrik.

\section{Sosialisme}

Daar moet vir ons doel kortliks onderskei word tussen sosialisme in die Westerse wêreld, dan binne die kader van die Marxisme, en dan sosialisme in sy Afrika-verband. Afrika-sosialisme is enersyds nie los te sien van die ander twee nie. Die betrokkenes wat hulle met 'n Afrika-sosialisme besig hou, het hulle vorming en opleiding of in die Weste òf in Moskou (en Peking) gekry, en hulle kultuuragtergrond is tot op sekere hoogte deur een van die twee rigtings bepaal. Andersyds word Afrika-sosialisme gekenmerk deur 'n strewe om los te kom van die ander twee rigtings, en om 'n eie, eiesoortige en kenmerkende sosialisme daar te stel wat "inheems" sal wees.

\section{Westerse sosialisme}

Die Latynse woord socius werp lig op die betekenis van die term sosialisme. Socius beteken letterlik bondgenoot of metgesel, een met wie jy geassosieer is. Sosialisme is 'n gedagtesisteem of lewenshouding waarin die idee van kameraadskap en samewerking sentraal is. Dit is ' $n$ reaksie teen die indiwidualisme, waarin die burgerlik-demokratiese beginsels van indiwidualiteit en persoonlike vryheid die belangrikste is, met die belange van die enkeling en sy welsyn bokant dié van die gemeenskap. Sekere regte en vryhede is vir die indiwidu gewaarborg, soos om regte en geleenthede te hê om produksiemiddele en ruilmiddele privaat te besit en te beheer. Eiebelang is gelegitimeer en staatsinmenging in die ekonomiese 
proses is uitgesluit. Die staat is beskermheer van hierdie status quo en hieruit is, kursories gesien, die grondslae gelê van die kapitalistiese ekonomiese stelsel.

In die loop van hierdie ontwikkeling het verskillende misstande te voorskyn gekom wat aanleiding tot wydverspreide ontevredenheid gegee het. Min mense het die meerderheid van produksiemiddele beheer, teenoor 'n groot besitlose groep wat gevolglik op ander lewensterreine ook in 'n ongunstige posisie verkeer het. Hulle het gevoel dat hulle uitgebuit is, dat hulle gekrenk is in hulle menslike waardigheid, selfrespek en trots. Die indiwidu het onbeskermd vereensaam.

Verset teen hierdie bedeling het beteken dat daar geëis is dat die kern van die saak reggestel moes word: Die ekonomiese bates moes regstreeks ten behoewe van die hele gemeenskap aangewend word. Op politieke terrein het die demokratiese beginsels reeds begin deurwerk (hier word nou van die vorige eeu gepraat), en dieselfde regte is nou op sosiale en ekonomiese terrein geëis.

Hierdie sosialiste het op sekere hoogte aangesluit by die reeds ontwikkelde kapitalistiese stelsel, maar wou dit deur en volgens 'n nuwe patroon verander en ontwikkel. Die ongewenste resultate van die kapitalisme moes verander word deur besondere maatreëls. Hierdie maatreëls het nie geweld of rewolusie uitgesluit nie. Sommige wou die remedie van die vakbonde gebruik wat sou stry vir beter lone en lewensomstandighede, by wyse van onderhandeling en (geweiiigde) stakings. Ander weer wou sien dat die staat self in 'n beperkte mate as ondernemer optree, sodat daar nuwe sektore sou ontstaan naas die private sektor van onderneming - 'n staatsektor of iets in kombinasie met die private. Die winste van die staat egter, moes vir die hele gemeenskap gebruik word, asook in die vorm van sekere subsidies vir die minder gegoedes.

'n Derde groep sosialiste was weer tevrede as die staat die ekonomiese lewe beheer deur die vasstelling van lone en pryse van goedere, om die loonarbeider teen uitbuiting te beskerm. Daarby kon die staat deur hoë belasting in die privaatsektor sorg vir 'n meer eweredige verspreiding van die algemene welvaart.

Daar het ' $n$ vry algemene opvatting bestaan dat die Christelike kerk hom aan die kant van die besittersklas geskaar het, en 'n antikerklike gevoel was merkbaar, hoewel hier nie sprake was van 'n prinsipiële ateïsme uit hoofde van die sosialisme nie. Net so was die sosialistiese optrede demokraties en vreedsaam, en het hoofsaaklik binne 'n kapitalistiese stelsel daartéén funksioneer, sonder dat gewelddadigheid 'n faset daarvan geword het. Die sogenaamde utopiste het in elke geval nog kan gesien om uiteindelike ideale toestand van volkome geluk vir elkeen te bereik. 


\section{Marxistiese Sosialisme}

Robert Owen was onder diegene wat nog gereken het dat ' $n$ ander moontlikheid sou slaag, en dit is dat die kapitaliste oorgehaal sou kon word om hulle stelsel heeltemal af te skaf sodat die produksiemiddele gemeenskaplik besit en beheer sou kon word. Die kommuniste egter was van oortuiging dat hulle dit nie vrywillig sou doen nie, en dat daar langs rewolusionêre weg 'n radikale struktuurverandering gesoek moes word. Dit moes begin met politieke rewolusie. Karl Marx was dieselfde opinie toegedaan, en ontwerp hiervoor 'n teorie wat beskryf kan word as allesomvattende denkpatroon. Vanweë die aard en opset van sy werk word gepraat van Wetenskaplike Sosialisme (ook Moderne Sosialisme en Radikale Sosialisme), want sy sisteem moes bewys dat daar vanweë bepaalde ekonomiese wette onvermydelik uiteindelik ' $n$ ondergang van die kapitalisme sou kom. Die kapitalisme stuur uiteindelik op 'n permanente krisissituasie af, waarin die klasbewussyn van die proletariaat ontplooi het en hulle hulself deur opstand bevry en so'n nuwe samelewing daarstel. Marx was hier besig met iets wat sowel teorie as metode genoem kan word.

In die Weste raak die benaming kommunisme sedert 1870 in onbruik, om plek te maak vir die term sosiaal-demokrasie. Hierin word die demokrasie sosiaal gefundeer en gerig. Geskiedkundig gesproke het daar in die Weste voortdurend woelinge ontstaan oor die noodsaak van radikaliteit (rewolusie en geweld) enersyds, en ' $n$ afgewaterde vorm, wat hervormingsgesind was. Hierdie sosiaal-demokrate het in hulle politieke partye naas ander sosialistiese partygroepe bestaan.

Wat die Marxistiese Sosialisme betref, moet onderskeidend op die volgende paar aspekte gewys word. Marx het dit so gestel dat die kapitalisme as sodanig sover sou ontwikkel dat die rewolusie plaasvind. Die proletariaat sou daarvoor verantwoordelik wees as hulle genoeg klasbewus geword het. Hierdie proletariaat was die loonarbeiders, eintlik die industriële loonarbeiders. Hulle moes met geweld die staatsmag afneern van die bourgeoisie en dit in hulle eie hande plaas. Na hierdie politieke rewolusie vind ' $n$ ekonomiese rewolusie plaas waarin alle produksiemiddele (landbougrond, fabrieke, myne, ens) gemeenskaplik besit en beheer word.

Wat hier tot stand sou kom, is 'n sosialistiese stadium wat tussen die voorafgaande kapitalistiese stadium en die daaropvolgende ware kommunisme lê. In hierdie stadium speel die staat 'n belangrike rol, en moes die staat sekere (kapitalistiese) take vervul alvorens dit vir goed van die toneel verdwyn. Die staat sorg vir die oorgang, kry ekonomiese bates in sy besit, laat die proletariaat werk en sorg dat die algemene ekonomiese peil opgeskuif word. Hierdie sosialistiese 
bewind is nie demokraties in die sin dat die meerderheid regeer nie, maar wel demokraties in die sin dat hulle namens en ten behoewe van die meerderheid regeer. Hiermee is mens by die prosesse van Lenin wat die praktiese probleme by die toepassing van die sisteem en metode ondervind het. Daar ontstaan proletariese sosialisme wat beteken dat die proletariaat die mag het soos die bourgeoisie dit in die kapitalistiese bedeling gehad het.

Daar is nog 'n belangrike faktor wat hier vermeld moet word. Dit is die aspekte van materialisme en ateïsme binne die kader van hierdie soort sosialisme. Die begrip materialisme hang saam met hierdie hele sogenaamde ontwikkelingstendens by alle dinge; dit berus op die stelling van teenoorstaande kragte wat inherent is in alle materie. Uit hierdie konflik van kragte kom verandering en verbetering voort, die noodwendigheid van ontwikkeling. Die ewolusie en rewolusie is onvermydelike, aanvullende komponente. Hierdie hele saak dien ook as 'n soort skeppingsleer waarby God oorbodig verklaar word. Hy bestaan bloot as ' $n$ projeksie van menslike verlangens en begeertes, gebore uit 'n staat van uitbuiting, onderdrukking, armoede en ellende. Godsdiens is 'n skepping van die heersersklas om die onderdruktes tevrede te hou, te laat verlang na ' $n$ beter en gelukkiger hiernamaals. Die mens moet egter van sy illusie verlos word waartoe hy homself gebring het omdat hy van homelf vervreem geraak het en homself nou misken as die belangrikste en hoogste wese. Feuerbach het godsdiens in indiwidualistiese terme benader, maar Marx as ' $\mathrm{n}$ sosiale probleem: Die slegte samelewing roep godsdiens in die lewe, om die huidige haglike toestande draagliker te maak en die ellendige mens te troos. Daarom moet dit verdwyn, die mens moet van fetišisme en vooroordele bevry word om homself in ware medemenslikheid en volkome vryheid te vind waardeur die groep en die massa tot sy reg kan kom.

\section{Afrika-sosialisme}

Hoewel al bogenoemde trekke in ' $n$ mate in Afrika aangetref word, afhangende van die bepaalde regime van ' $n$ land, kom daar in hierdie sosialisme 'n heel eiesoortige trek te voorskyn.

\section{Afrika}

Afrika met sy mense is bepalend vir die siening van sy eiesoortige sosialisme. Sosialisme het immers met die mense te doen, met die broederskap van mense, met hulle gemeenskaplikheid. Afrika se massas is nie verniet ingedeel onder die term Derde Wêreld nie. "African Socialism is an expression of the desire of all Africans to find themselves, be themselves, and assert themselves"1. 
Daar kom 'n redelik algemene sienswyse na vore by 'n ondersoek van hierdie onderwerp, en dit is dat die mens van Afrika 'n ontredderde en misbruikte mens is - uitgebuit deur kolonialisme en die vrugte van kapitalisme. In hierdie stadium van die geskiedenis bestaan daar nog eintlik nie begrip en waardering vir die positiewe faktore wat die meelopers van veral die koloniale tydvak was nie - ten spyte van sekere negatiewe elemente. (Hier word gedink aan die tegnologiese ontwikkeling en ontginning van Afrika se potensiaal, die ordelike en ordende regeringsvorms, die algemene verhoging van lewenspeil, gesondheidsdienste, bestryding van hongersnood, e.s.m.)

Die uitgangspunt van 'n Afrika-sosialisme is die heersende toestand van armoede en ellende. "There can only be one point of departure, namely, that black skeleton of a man, hungry, half-naked, sick, frustrated, lying on a narrow wooden board beside an open fire-place, in his dingy hut of mud walls and thatched roof, with a low door, without a window, sharing the same room not only with his entire family but also with animals"'2. Die denke waaruit Afrikasosialisme gevorm en beoefen word, berus op hierdie prentjie en nog baie meer: Ook op die vernedering wat deel is van die Afrikaan as gevolg van die minagting wat die gevolg is van sy velkleur, die aard van sy kultuur en sy gepaardgaande plek in die gemeenskap. Wie dit nie raaksien nie, sal moeilik begrip hê vir die politiek en sosialisme van Afrika.

Staatsmanne en geleerdes in Afrika het teruggeval op die sosialistiese patrone waarmee hulle in die loop van hulle eie vormingsjare en eietydse geskiedsgebeure gekonfronteer is, maar algaande het die bepalende faktor tog die mens van Afrika geword. Dit het meegebring dat die Afrika-sosialisme beslis nie net met die ekonomie te make het nie.

Hierdie spesifieke mens-betrokkenheid het gemaak dat die Afrikaan in sy agtergrond en stamverband betrokke geraak het. "We could say that African Socialism is the modernization of traditional African communitarism ... African Socialism is not a doctrine of idiological abstraction, but a way of life" ${ }^{\prime 3}$. "It must be defined in psychological and sociological terms - in terms of a will, an attitude, a people, a conception of life - as well as in economic and political terms"

\section{Kultuur}

Waar oor die mens gepraat word, kom onafwendbaar sy kultuur ter sprake - die vanselfsprekende produk van sy geestesarbeid. Dit is veral die staatsman van Senegal, Léopold Senghor, ook genoem die vader van Afrika-sosialisme, wat reeds in die veertigerjare hierdie 
aspek sterk na vore gebring het. As filosoof en digter, met geen geringe invloed in daardie politieke tydperk in Frankryk self nie, is dit begryplik dat hy hierdie aspek duidelik sou omlyn. "African politicians have a tendency to neglect culture, to make it an appendage of politics. This is a mistake. They ... are certainly closely connected, each reacting on the other. But if one stops to reflect, culture is at once the basis and the ultimate aim of politics ... Culture is also basic in the socialist connotation of the word. It is "the sum of objects, ideas, symbols, beliefs, feelings, values, and social form that are transmitted from one generation to another in a given society" $\ldots$ "Culture is the very texture of society" .

Senghor is iemand wat ' $n$ totale vervreemding waarneem by die mens as gevolg van die verskynsel van kolonialisme. So iets kan geen onafhanklikheid bring nie. Sy groot strewe is na kulturele onafhanklikheid, die enigste wat onafhanklikheid op politieke, ekonomiese en maatskaplike terreine kan bied Om daartoe te kom moet geveg word - nie met die geleende wapens van die Europese proletariaat, wat beweer dat die stryd van die Europeër en die Swartman van Afrika identies is nie; dan gebeur dit dat beskawing en vooruitgang Europees sal wees. Hy is die skepper van die begrip Négritude, "the common denominator of all Negro Africans"7 , of as volg gedefinieer: "Négritude is simply the totality of civilizing values of the Negro world"8. Hy soek dus vir hierdie sake die eie idioom.

Dit moet egter hier gesê word dat hierdie saak van die kultuur ten nouste aansluit by die godsdiens van Afrika en die godsdienstige in sy sosialisme. Daarop word teruggekom.

\section{Die eie weg}

Dit is egter nodig om nog die volgende aspekte van Afrika-sosialisme te vermeld alvorens ons opsommenderwys die elemente van hierdie sosialisme saamvat.

Tot by Mosambiek was die sosialisme in Afrika meer afwysend teenoor die Marxistiese model, minder afwysend teenoor die Europese of Westerse. Senghor, gedrenk in die Franse kultuur, toon sy waardering duidelik, maar spel die verskille uit - verskille wat veral in ander Afrika-state wys op die eie soeke na sosialisme, gewoonlik met 'n verwysing na Pan-Afrikanisme - "...'n kragtige middel ... om Pan-Afrikanisme te bevorder, en selfs dat dit die hele mensheid tot lig en leiding kan strek - "die deur kan open vir 'n nuwe sosio-ekonomiese orde en 'n nuwe beskawing"'.

Kritiek op die Westerse kapitalisme spruit veral daaruit dat toestande in Afrika heel anders as in Europa is. Vir ons doel moet gelet word op die verwyt dat die kapitalisme onreligieus is, want dit gee nie aandag aan die Christelike gebod van broederskap nie. Hierdie 
versuim blyk op die ekonomiese en sosiale lewensterreine, al is die kapitalisme nie teen godsdiens nie. Afrika-sosialiste beweer dat die kapitalisme materialisties is.

Dieselfde besware word nie altyd teen die Westerse sosialisme ingebring nie, maar hulle wys ook op die materialistiese aard van hierdie sosialisme. Basies is die verskil die totale ander agtergrond van Westerse-sosialisme.

Wat die Kommunisme betref het Senghor hom al teen die ateïsme daarin uitgespreek, en in die algemeen deel Afrika-sosialiste hierdie opinie. Hieroor is geskryf: "Chinese kommunes het die gesinslewe onteer; die Russiese Kommunisme verwerp God en die gees wat in die mens is"10.

Omdat die verskille origens baie omvangryk is, volstaan ons met 'n beskrywende aanhaling van Senghor: "We stand for a middle course, for a democratic socialism, which goes so far as to integrate spiritual values, a socialism which ties in with the old ethical current of the French socialists"11.

Dit is goed om na die ontleding van die elemente van Afrikasosialisme te kyk soos dit uiteengesit is deur die Roomse ampsdraer, die Nigeriër Bede Onuoha.

\section{Die beginsels van Afrika-sosialisme}

Voordat die huidige beginsels bekyk kan word, is dit nodig om 'n oomblik terug te keer na die ou leefwyse van Swart Afrika en dit te analiseer, want die meeste ondersoekers aanvaar dat Afrika-sosialisme ' $n$ poging is om die ou kommunale praktyke van die Swartes weer te laat herleef op'n gemoderniseerde patroon.

'n Analise toon die volgende elemente waaruit die beginsels van sosialisme afgelei is.

\section{1}

Daar is die groter familiekring (heel anders as die Westerse voorbeeld) van grootouers, man met ' $n$ paar vrouens en heelwat kinders. Hier het ' $n$ bepaalde werksindeling gegeld.

\section{2}

Die stat, waarin die paar groepe 'n besondere solidariteit geken het.

\section{3}

Die stam, by wie ooreenkoms en samewerking tot op groot hoogte gegeld het sonder klasseverskil.

\section{4}

Die kaptein, wat sy leierskap uitgeoefen het sonder 'n kommune, 
maar waarby sy raad inspraak gehad het in ' $n$ besondere samesnoering van monargie, aristokrasie en demokrasie.

\section{5}

Die oudstes het 'n besondere plek beklee, en samespreking was met verskil en al daarop gemik om uiteindelik konsensus te bereik.

\section{6}

By die mense was daar 'n element van solidariteit, en die eienskap wat beskryf is as tradisionele kollektivisme, kommunitarisme en Afrika-humanisme. Sekou Touré het van die term "communaucratique" gepraat.

\section{7}

Die priester het nie ontbreek nie. Hierdie element impliseer dat daar geen ateïsme was nie (Ons is eerder geneë om van die toordokter te praat aan wie se optrede en invloed ons ' $n$ groot mate van bygeloof verbind). Die feit is dat die animisme die ou godsdienstige stroming in Afrika was, en onder talle vandag nog die godsdiens beliggaam. Die Islam en Christendom het die beduidendste invloed gehad om gedeeltes van die inheemse godsdiens te laat verdwyn, natuurlik nie sonder dat die reste daarvan geassimileer is of nog op ' $n$ bepaalde manier as oorblyfsel 'n invloed op die nuwe godsdiens uitoefen nie.

In die opset onder bespreking moet ons die godsdiens nie onderskat nie. Dit is bekend dat die Afrika-mens "ongeneeslik religieus" is. Die religieuse is in al die lewensuitinge sigbaar en speel 'n rol op alle lewensterreine - regering, regspraak, ekonomie en sosiale lewe. Natuurlike verskynsels word in bo-natuurlike terme geïnterpreteer. Hy sien in God alles. Sy maatskappy is geestelik. Geestelike werklikhede is vir hom meer reël as die materiële. Die natuur en kosmos is beliggaam met geeste. Die optrede van die toordokter maak die lewe self tot godsdiens, baie meer as die uiterlike nakoming van godsdienstige pligpleginge.

Nou is hierdie patroon die bloudruk van Afrika-sosialisme. Onuoha doen moeite om in hierdie verband te beklemtoon dat Afrika-sosialisme nie imitatief is nie, maar her-skeppend. Hier het 'n her-ontdekking plaasgevind van die Afrika-mens en daarmee 'n terugkeer tot die wysheid en waardes van hulle voorvaders. In hierdie eeu van beginsels, so redeneer Onuoha, is dit nodig om filosofie te gebruik ten einde ' $n$ bestendige rasionele en begryplike standpunt daar te stel ten opsigte van die maatskappy en die kosmos. (Interessantheidshalwe kan opgemerk word hoe Senghor baie verder gaan en duidelik onderskeid maak tussen die denkpatrone van die Europese denker en die Swartman. Hy praat spesifiek van "Negro- 
African knowledge". "From our ancestors, we have inherited our own method of knowledge. Let us then consider the Negro African as he faces the object to be known, as he faces the Other: God, man ... or social phenomenon. In contrast to the classic European, the Negro African does not draw a line between himself and the object; he does not hold it at a distance, nor does he merely look at it and analyze it, he takes it vibrant in his hands. He touches it, feels it, smells it. The Negro African is ... a pure field of sensations ... Thus the Negro African sympathizes, (Frans: sym-pathise, letterlik "voel met") abandons his personality to become identified with the Other, dies to be reborn in the Other. He does not assimilate; he is assimilated. He lives a common life with the other; he lives in a symbiosis ... Subject and object are dialectically face to face in the very act of knowledge ${ }^{\prime \prime 12}$.)

Die term Afrika-neo-sosialisme word al meer gehoor, vanweë verstaanbare redes. Onuoha gebruik die woord ook so vir sy agt "praktiese" beginsels wat hier kortliks vermeld word.

1 Broederskap

Dit sluit aan by die verskynsel van die uitgebreide familie.

2 Leierskap

Die belangrike hier is die element van kontak in die mens-verbande, en geld veral die nuwe leier van vandag.

3 Dialoog

Konsensus moet bereik word, en dit is 'n waarborg teen diktatuur en geweld. Die Afrika-mens sien dié stelsel heel anders as ons vanuit die Westers-demokratiese hoek.

\section{Beplanning}

Hier is 'n noodsaaklike faktor in die omstandighede wat ' $n$ moderne tyd meebring. Verskillende elemente - en dit is opvallend - van politieke ekonomiese en sosiale ordes moet geïnkorporeer word om 'n gebalanseerde uitweg uit enige chaos te verseker.

5 Harmonie

Dit moet verdeling en (klasse-)stryd uitskakel.

6 Autonomie

Daar moet onafhanklik gebly word, met 'n nasionalisme wat Pan-Afrikanisme sal akkommodeer.

7 Positiewe neutraliteit

As onverbondenes moet almal veral die belange van Afrika dien.

8 Pan-humanisme

Dié wil verseker dat die hele wêreld volgens hierdie beginsels ware Sosialisme tot sy logiese konklusie voer. Interafhanklikheid, erkentlikheid van waardes en opregte humanisme is deurslaggewend, wêreldwyd. 


\section{Afrika-sosialisme en religie}

Hierbo is reeds, waar dit van toepassing was, gewys op die verbande wat daar met die godsdiens bestaan, asook op die rol van godsdiens ten opsigte van die sosialiste se benadering van hierdie saak wat van so 'n sentrale belang is in die bestaan van die volke en groepe in Afrika in die ontwikkeling van state en die stabilisering van nasionaliteite, asmede die lewensvatbaarheid en groei, materieel gesien, ekonomies dus.

\section{Godsdienste in Afrika}

Dit is vir ons doel nodig om die tipiese Afrika-produk as animisme te omskryf, en so die verskeidenheid gelowe, gebruike en kultusse saam te vat. Dit is tiperend van die belewenis van die skriflose volkere van wat hulle as geestelik en heilig beskou, en in baie dele het toenemende beskawing dit min verander. Hulle aanvaar steeds die bestaan van 'n geestelike werklikheid wat sin, waarde en rigting aan alle menslike strewe gee.

Die Islam en die Christendom is die enigste twee ander beduidende strominge in Afrika. Hulle het hierdie Afrika-mens aangetref as 'n wese wat allermins afkerig was ten opsigte van godsdienstige betrokkenheid. Hulle ganse kultuur was ontvanklik vir godsdienstige impulse, en die waarnemers uit Afrika self beskrywe die vooruitgang van hierdie twee godsdienste in hierdie terme - dit wil sê dat die kultuur sodanig was dat dit maklik hierdie godsdienste 'n plek kon gee, en kon toelaat om 'n stempel af te druk op hierdie mense en hulle lewensuitkyk en milieu. Kultuur en godsdiens hang dus ten nouste saam.

Oor die resultate van die koms van Islam en Christendom is daar verskillende interpretatiewe moontlikhede. Onuoha sien enersyds die moontlikheid dat dit die sterk geestelike inslag van die Afrikamens ontwikkel en vervolmaak het; in ander gevalle dit verarm het; maar dit darem meer gesofistikeerd gemaak het, en ' $n$ mate van organisasie gebring het tot die vlak van die denominatiewe.

\section{Verband van Afrika-sosialisme met godsdiens}

Wanneer hier van godsdiens gepraat word, is die saak nie so eenvoudig dat veral een van die gemelde drie voorbeelde, animisme, Islam of Christendom geneem kan word nie. 'n Synkretisme kan ook nie voorgehou word nie, want eintlik kom hier 'n ander aspek ter sake. Dit is so vanweë die gangbare opvatting van wat godsdiens vir die betrokkenes is wat met hierdie sake werk, en soos dit afgelees kan word uit die algemene gebruik van hierdie begrip godsdiens. 
Juis vanweë die onlosmaaklike verband met die kultuur van die mense, kan daar gepraat word van die sogenaamde "end-product of all religion"13. Aan hierdie eindproduk van alle godsdiens moet Afrika-sosialisme eng verbind word.

Hierdie eindproduk van godsdiens word soos volg uiteengesit. Mens het naamlik hier te make met

1 Die kuluts van God, die Hoogste Wese, wat nie anti-humanisties is nie, maar die Gewer van lewe.

2 Die bevordering van die voorrang en relevantheid van die geestelike in menslike bedrywighede.

3 Die konkrete verwerking van die broederskap van die mens.

Op hierdie drie aspekte is godsdiens afgespits; hierom gaan godsdiens. As 'n beweging soos Pan-Afrikanisme nou 'n waarde-oordeel vel oor 'n godsdienstige gemeenskap, sal die maatstaf bogenoemde drie sake wees, en daar sal op gelet word of hierdie sake effektief bevorder word. Hier word verklaar dat Pan-Afrikanisme nou die beoordelaar is - dit val mens op. Dit is egter so omdat die maatskappy, die gemeenskap van mense ter sake is, en hulle vra na die effektiwiteit, die dinamisme, die geestelike dryfkraf van die verskynsel godsdiens onder mense. Ander uitsprake word oorgelaat aan die afsonderlike verskyningsvorme van godsdiens self om te oordeel oor sake soos waarheid/valsheid en so meer. Daar mag net geen afbreuk gedoen word aan enigiets wat die geestelike in die mens (en dit geld eintlik kultuur) sal belemmer, of wat hindernisse tussen mense sal plaas of wat formalisme, institusionalisme of groeperinge sal bevorder nie.

Wanneer die uitsprake van staatsleiers in hierdie verband nagegaan word, tref dit dat sosialisme nie sonder die kultuurgoedere en geestelike rykdom gesien word nie, en dan word godsdiens onder dieselfde noemer gebring. By die strewe na materialisme, by wyse van 'n hoër lewenstandaard en wat daarmee saamgaan, is die sine qua non ' $n$ hoër kultuurpeil ${ }^{14}$.

Reeds in 1962 verklaar Tsiranana van Malagassie dit wat die logiese konsekwensie ten opsigte van godsdiens is: "I strongly hope that our intellectuals and our priests and pastors integrate themselves into our national life $e^{\prime 15}$. In 1980 hoor ons 'n soortgelyke geluid in die nuutgestigte staat van Zimbabwe as sy president Banana oor die verhouding tussen staat en die bestaande geïnstitusionaliseerde kerkgroepe dieselfde verklaar. "(The Church) would have to come to terms with the demands of a changing situation, and adjust to the new social order"16. Vanuit hierdie staat skryf ds Thinus Boshoff (Geref Kerk, Salisbury) dat godsdiensvryheid "kan alleen binne die weg van sosialisme bestaan"17.

Voordat 'n meer algemene uitspraak oor die verhouding van gods- 
diens en Afrika-sosialisme gegee word, is dit tog insiggewend om op enkele uitsprake van Canaan Banana te let, van wie gesê word dat hy oor 'n teologiese opleiding beskik, sodat hier spesifieke verwysinge na die Christelike godsdiens is.

Wat die taak en rol van die kerk betref, meld hy: "It is not enough to preach and pray about the human situation. One has to take positive and direct action to redress the social inequalities ... Churches should be instruments in supporting (the government approach)"18.

Oor die wese en godsdiens (en teologie) kry mens die aanduidings van konsensus met veel wat reeds gesê is, hoewel die moontlikheid bestaan om heelwat ander teologiese afleidings te maak. "Of necessity, one's own theological outlook has to find its basis from one's own background and experience ... My understanding of religion stems from the struggle to be free ... When I see a guerilla, I see Jesus Christ. The Gospel says that "greater love has no man than this ... that he can lay down his life for his friends." When I see a guerilla, I see this happening. The guerilla dies so that we may live" ${ }^{\prime 19}$.

Uiteindelik het mens aangekom by die aangepaste godsdiens of die gesosialiseerde evangelie, wat so soet klink in die oor van die wêreldbroederskap en die soekers na 'n eenheid onder die mensdom volgens die patroon wat vooraf uitgekies, afgegrens en verhef is tot 'n godsdiens op sy eie, omdat elke ander poging as seksionalisties, vyandig en ondergrawend gebrandmerk staan. Dit is goed om die sogenaamde positiewe kortliks te beluister:-

Geestelike en morele neutraliteit kan nie geduld word nie - dit loop op nasionale selfmoord uit, want die vindende faktore by 'n volk kan net geestelik wees. Materie is 'n verdelende prinsipe. PanAfrika-eenheid is net deur 'n geestelike herontwaking te smee, 'n herontwaking waardeur die bindinge van egoïsme, tribalisme en nasionalisme verbreek kan word, juis ter wille van hierdie Pan-Afrikanistiese ideaal wat skyn 'n wesenlike element te wees van hierdie tipe sosialisme.

Daar is nie te twyfel oor die waarde van godsdiens nie. "We need religion to inculcate the infinite value of human life, respect for other people's rights, the correct use of authority as a service to the public, the spirit of equality, justice and brotherly love ${ }^{20}$.

Die feit dat godsdiens beklee word met 'n funksie, 'n taak, moet duidelik hier uitgewys word; asook die feit waarvoor hierdie funksie gebruik word. Godsdiens sal die geestelike talente en bates van die mens ontsluit - tot ander en verdere werksaamhede en potensialiteite. Godsdiens sal nuwe waarde aan menslike lewe en aktiwiteite gee. Die sosialistiese staat sal dus hierdie denominatiewe werksaamhede van godsdienstige inrigtings gebruik en toelaat - tot op 'n 
punt: Dit durf nie usurpeer en een geloof propageer nie. Die vryheid van elk tot godsdiens word verseker.

Vir sover daar samewerking is tussen die staat en die kerk, word dit gebaseer op skeiding tussen kerk en staat ${ }^{21}$. Opmerklik is egter die woorde van Isaac David Mahlalela, Sekretarisgeneraal van die Christelike Raad van Mosambiek: "es sei die Pflicht der Kirche, der Regierung zu helfen da" das, was sie für das land tut, gut ist" ${ }^{\prime 22}$. (Ook opvallend is die verdere getuienis van hierdie kerkleier van talle Vrye Metodistiese Kerke van Mosambiek dat: "Die paramarxistische Befreiungsbewegung" Frelimo, die 1975 in Mosambiek an die Macht kam, habe ihn gelehrt, die "Rolle der Kirche besser zu verstehen". Das Evangelium verkünden bedeute, auf die Bedürfnisse aller Menschen ausgerichtet zu sein, ob sie an Gott glaubten oder nicht ${ }^{\prime 23}$. Dit word duidelik dat mens nie al te veel aandag aan hierdie situasie kan gee nie - die NG-sending het hiervan genoeg ervaring beleef.)

Origens, vir die staat (die sosialistiese staat in hierdie geval) is die strewe van die kerk (waardeur ons nou maar die godsdienstige strewe aandui, want die staat ervaar die sogenaamde eindproduk van religie tog maar in sy konkrete uitinge) 'n kosbare produk; sê nou maar as die Christelike ekumeniese strewe uitgebrei kan word en nie net beperk bly tot Christene nie.

' $n$ Gees van grote verdraagsaamheid is die ideaal veral vir Moslems en Christene wat moet leer om mekaar te verdra en hulle gemeenskaplike uit te bou, wat geleë is in 'n onverdeelde burgerskap en medemenslikheid. Fanatisme met al sy negatiewe faktore is ' $n$ ellende wat nie bekostig of geduld kan word nie. Die "goeie" werk van die kerk is allesbelangrik.

Samevattend is daar ' $n$ besliste positiewe waardering van die godsdienstige in die mens, en van die produkte hiervan. Die rol van dié sake in die maatskappy is hoofsaaklik oorsaak van die afwysing van die Kommunistiese beoordeling van godsdiens wat dit verwerp as menslike vindsel tot verdowing van leed. Hierdie positiewe waardering van die godsdienstige is gebore uit 'n beskouing wat inherent in die godsdienstige die sleutel sien tot ontsluiting van menslike hoogstaande waardes, soos veral die moontlikheid om die mens te dien, hom in sy samelewing te dien, hom te bevry, die kwaad te bekamp en uit te bou, en sosiale euwels uit te skakel sodat die mens homself volkome kan uitleef en verwesenlik. Die hele beskouing van die godsdienstige word hierop gerig en ' $n$ waarskuwende woord gespreek oor die engheid van die godsdiens, waarin "bevryde" mense aan bande gelê, voorgeskryf, inperkende en beperkende maatreëls opgelê en die institusionalisme bevorder word. Waarlik militante en offensiewe godsdienstige mense kan volgens patroon van die sosialisme die vryheid, welvaart en geluk van die groep tot 'n uiters doeltreffende vlak voer. (Die ingeligte leser is daarvan 
bewus dat die "in-ding" onder baie gelowiges in Europa 'n "Christelike" Sosialisme is; in die Afrika-konteks is daar nie sprake van ' $n$ "Christelike" Sosialisme nie.)

Hier moet begryp word dat die diskoers noodwendig 'n redelik algemene gang volg. In die verskillende Afrika-lande verskil die bloudrukke van sosialistiese opbou en ideale, en die uitsprake van staatsmanne sal nie in alle opsigte ooreenkom nie. In resente tyd, veral met die onafhanklikwording van Mosambiek en Angola, tref mens die afwykings aan, asook die aanpassings wat deur praktiese (politiek) oorwegings, ekonomiese bande en gewoonmenslike basiese behoeftes (voedselvoorsiening) genoodsaak word.

\section{Beoordeling}

\section{Sosialisme self}

Dit het duidelik geword dat die Sosialisme as ' $n$ bepalende sisteem sekere oogmerke het en aansprake maak wat verband hou met die uitwerking van die godsdienstige. Dit wil die mens en sy bestaan omvat en versorg en sy toekoms verseker. Hiervoor moet die heersende orde, die politieke, ekonomiese en maatskaplike sisteem volgens die nuwe voorgeskrewe patroon verander word. Die Sosialisme kan hiervolgens as 'n ideologiese getipeer word. Hierdie reël vir die lewe, die wêreldbeskoulike, toon ons die religieuse aspek daarvan. Maar terselfdertyd moet dit as ' $n$ dwaalleer beskryf word, omdat die aansprake nie die waarheid is nie.

Vir die Sosialisme, en dit geld alle vorms daarvan, is die towerwoord verandering. Hierdie verandering moet ' $n$ absolute wonder bewerkstellig. Dit moet die politieke toestande verander, die ekonomie met 'n towerslag verbeter, die maatskaplike orde se peil verhoog. Daar moet vryheid kom, met vrye spraak en uitdrukking vir elkeen; daar moet gelykheid kom deurdat die groot verskil tussen ryk en arm verdwyn, daar moet ' $n$ broederskap tot stand kom wat die menslike vooroordele en vyandskap sal uitwis, omdat die oorsake daarvan nie meer sal bestaan nie. Dit is die bedoeling en belofte van die sosialisme om ook, soos ander ideologieë, af te stuur op 'n utopie. Wie daaraan vasklem, loop op die pad van die bygeloof. Vir hom het die Sosialisme ' $n$ allesomvattende, oorkoepelende, oorheersende, voorskrywende en allesbepalende ideologie geword.

Sou 'n teëwerping dat Afrika-sosialisme tog van hierdie vooropgesette kritiek verskil, omdat dit godsdiens aanvaar en die godsdienstige gebruik, enige verskil maak? Ongelukkig nie, vanweë 'n paar redes wat uitgestippel moet word. Godsdiens word hier misbruik, omdat dit bloot middel tot 'n doel word - die doel van die sosialisme, die Afrika-ideaal daarvan, soos uitgewerk deur sy denk- 
ers, staatsmanne en idealiste - selfs die nuwe geslag uitbuiters. Mense met eie, selfsugtige, bose motiewe het nie nou eensklaps verdwyn nie.

Dit is trouens die groot probleem. Sy verandering is nie verbetering nie; sy nuwe sistematisering bring nie geluk nie; sy verdeling van goedere bring nie rykdom nie. Die lewe van die sosialisme kan so beskryf word: Armoede is geïdealiseer, rykdom is verdoem. Armes is die uitgebuite edeles, rykes is die bose, sondige uitbuiters. Maar is armes edel, omdat hulle arm is? En rykes sleg, omdat hulle ryk is? Verder openbaar hierdie verdeling in Afrika hom al sterker ten opsigte van 'n Swart-Wit afgrensing waaraan dikwels dieselfde logika toegeken word. As almal maar net in dieselfde mate gelyke geleenthede kry, as almal maar net in dieselfde klas onderrig kan word, as die massa maar eners gesien, behandel en beoordeel word, seëvier vryheid, gelykheid en broederskap. Maar 'n godsdiens wat praat van 'n God wat aan elkeen volgens sy maat toebedeel, wat gee en neem na sy wil - dié word tot orde geroep, en gevra om te konformeer na die normvoorskrywende inheemse kultuur.

So gesien, dra Sosialisme nie die gees van die waarheid nie, maar die gees van die ideologie. Die Gees van die Waarheid word deur die Skrif anders beskrywe. So 'n verhorisontaliseerde godsdiens kan niks anders wees as die diens van afgode nie, iets wat die mens, so raakgesien het, dat dit van God vergeet het.

\section{2}

'n Volgende belangrike vraag is, wat die Sosialisme aan die godsdiens hét, teen hierdie agtergrond van toleransie, aanvaarding en aanwending daarvan. Die sleutel lê vir ons opgesluit in die geweldige aksentuering van die kultuur. Afrika-sosialisme sluit by die mens en sy kultuur aan - nee, dit word produk en uitvloeisel daarvan. Eintlik sou die ou Afrika-godsdienstige outonomie van die godsdiens opgeoffer word voor die nuwe gode van vryheid en gelykheid. (Waarby al vergeet is dat reeds Aristoteles daarop gewys het dat vryheid ongelykheid voorbring, en dat algemene gelykheid onvryheid impliseer. 'n Gelykmakery en vryheid is nou eenmaal krasse teëstelling.) Godsdiens word middel tot 'n doel, en in die proses word ook wat ons volgens die Christelike geloof as die ware godsdiens sien, demonies verwring.

Dit is dan net 'n enkele tree tot die gedagte dat die godsdienste tolerant moet wees, dat hulle moet saamwerk, dat hulle terug te voer is tot die gemeenskaplike noemer, die kultuur. Godsdiens is ontdaan van sy uniekheid (nou: gaan ons oor tot die Christelike geloof en spreek verder daarvan), van sy openbaringskarakter, en hy word opgeoffer aan die nuwe remedie en heilmiddel - die Sosialisme. 
Hiervan word nou verwag, die ideale toestand en gelykheid van mense, sonder begrip vir die sonde wat die utopie onmoontlik maak. Hiervan word die deugde van ware naasteliefde, van selfwerksaamheid ter wille van die ander, van gelykheid voor die aangesig van hierdie sisteem gesoek, sonder begrip van daardie Heer wat die reël van die liefde in sy wet gee, wat sy gawes uitdeel soos Hy wil - vir die een wysheid, vir die ander mag, vir 'n volgende rykdom; die Heer wie se wil in hierdie sake ondeurgrondelik is, maar wat tog duidelik die sin van alle bestaan daarin bepaal dat Hý die Alfa en die Omega sal wees, dat Hý geken, geëer en gevrees sal word.

Afrika-sosialisme misluk uiteindelik daar waar dit saak maak, omdat die inhoud van die ware godsdiens getoon het dat vyf brode en twee vissies nie blywende versadigheid bied nie. Hy self het getoon dat die vlees en die bloed van die ewige Seun van God daarenteen 'n spys en drank van die ewige lewe geword het.

Die kerk het hiermee ' $n$ geweldige getuienistaak gekry in die heersende omstandighede van Afrika. Geen kerk het seker groter taak as ons wat in Afrika woon en die realiteite beter ken - en ervaar - as mense elders nie.

\section{BRONNE}

Bede Onuoha. The Elements of African Socialism. Andre Deutsch Ltd 1965. Léopold Sédar Senghor. On African Socialism. Pall Mall Press 1964.

D J Kotzé. Kommunisme Vandag. Tafelberg 1977.

Hervormd Nederland 14 Maart 1981.

Informationdienst der Evangelischen Allianz, idea nr 55/80 vom 9 Oktober.

Alexander Evertz. Die sozialistische Irrlehre. Uit: Erneuerung und Abwehr Okt/Nov 1980.

\section{BRONNEAANWYSINGS}

1 Onuoha aw p 30

2 Ibid p 23

3 Ibid $\mathrm{p} 123$

4 Ibid $p 124$

5 Senghor aw p 49, aanhaling van Nilakanta Sastri, "L'Avenir des Cultures traditionnelles, "Chronique de l'Unesco 1959.

6 Senghor aw $p 49$

7 Ibid pvi

8 Ibid pvi

9 Kotzé aw p 28

10 Ibid $\mathrm{p} 34$

11 Senghor $p 46$

12 lbid p 72-73

13 Onuoha p 104

14 Senghor Nation et Voie, aangehaal deur Onuoha p 105

15 Onuoha $p 106$

16 The Herald, 21-11-1980 
17 Die Beeld, 31-3-1981

18 Herald 21-11-1980

19 Ibid

20 Onuoha p 106

21 Ibid

22 idea nr 55/80 9 Oktober

23 Ibid 